\title{
Investigating the influence of histidine residues on the metal ion binding ability of the wheat metallothionein $\gamma-E_{c}-1$ domain
}

\author{
Katsiaryna Tarasava, Eva Freisinger* \\ Department of Chemistry, University of Zurich, Winterthurerstrasse 190, 8057 Zurich, \\ Switzerland. \\ *Corresponding author: Tel.: +41 44 6354621; fax: +41 44 6356802; E-mail address: \\ freisinger@chem.uzh.ch
}

This work is dedicated with the best wishes to Professor emeritus Milan Vašák on the occasion of his $70^{\text {th }}$ birthday

\begin{abstract}
While $\mathrm{Zn}(\mathrm{II})$ and $\mathrm{Cd}(\mathrm{II})$ have similar geochemical and environmental properties, their biological properties are distinctively different as $\mathrm{Cd}(\mathrm{II})$ ions have very limited metabolic significance and are mostly even toxic, while $\mathrm{Zn}(\mathrm{II})$ ions belong to the most essential micronutrients. One of the key proteins involved in intracellular $\mathrm{Zn}$ (II) and $\mathrm{Cd}(\mathrm{II})$ binding are metallothioneins (MTs), small cysteine-rich proteins ubiquitously found in many different organisms. In the past two decades, also MT sequences from diverse species that contain histidine residues have been found, and His-metal ion coordination has been shown. It is not clear, however, why in some MTs part of the Cys residues are replaced by His, while most other MTs only contain Cys residues for metal ion binding. To address this question, we used the $\gamma$ domain of the early-cysteine labeled $\left(\mathrm{E}_{\mathrm{c}}-1\right)$ metallothionein from common wheat as a model system because its enclosed $\mathrm{M}_{2} \mathrm{Cys}_{6}$ cluster represents the smallest metal-thiolate cluster possible with divalent metal ions. Based on the known three-dimensional structure of the $\gamma$-domain we set about to investigate the influence of a single Cys-to-His mutation on the structure and metal ion binding abilities of this domain. Combined data obtained by mass spectrometry, UV, as well as NMR spectroscopy suggest a preference for $\mathrm{Zn}(\mathrm{II})$ versus $\mathrm{Cd}(\mathrm{II})$ ions in the histidine containing binding site.
\end{abstract}

\section{Keywords}


Metallothionein; Histidine; Zinc; Cadmium; Metal ion specificity 


\section{Introduction}

Understanding the pathways of metal ion distribution has moved into the focus of interest in the last few decades, but many aspects still remain unclear, for example, how cells can distinguish between different metal ions with rather similar properties, decide which metal ions need to be transferred to metalloenzymes and which have to be eliminated from the cytoplasm due to their toxicity. As $\mathrm{Zn}$ (II) and $\mathrm{Cd}(\mathrm{II})$ both belong to group IIB of the periodic table and hence have the same number of valence electrons ( $\mathrm{d}^{10}$ elements) and the same valence state they resemble each other in their geochemical and environmental properties. Their biological properties are, however, distinctively different. $\mathrm{Zn}$ (II) ions belong to the most essential micronutrients. As metal cofactors they play fundamental roles in many enzymatic reactions or are important for specific protein structures that are, e.g., required for the regulation of gene expression.[1] Replacement by Cd(II) generally, but not always, leads to a decrease of the activity or even complete loss of function mostly due to the lower Lewis acidity of the Cd(II) ion or its larger ionic radius that can cause distortions of the structure.[2] A prominent example for a functional $\mathrm{Cd}(\mathrm{II})$-containing enzyme is a carbonic anhydrase isolated from a marine diatom.[3] Pollution with cadmium is mainly man-made, it has entered into the biogeochemical cycles, and can affects human health (for example, the Itai-itai disease was caused by $\mathrm{Cd}(\mathrm{II})$-contaminated rice in Japan).[4] Especially for organisms such as plants, which are in direct contact with the soil, from which all mineral nutrients are taken up, discrimination between metal ions in general, and between $\mathrm{Cd}(\mathrm{II})$ and $\mathrm{Zn}(\mathrm{II})$ in particular is of great importance.

One family of proteins suggested to interact with $\mathrm{Zn}(\mathrm{II}), \mathrm{Cd}(\mathrm{II})$, and $\mathrm{Cu}(\mathrm{I})$ ions within the cell are the metallothioneins (MTs).[5] MTs are low molecular mass proteins with an extremely high cysteine content that allows them to bind metal ions, preferentially with a $\mathrm{d}^{10}$ electron configuration, in form of metal-thiolate clusters. MTs are widespread in nature. They are proposed to play a specific role in the storage and transport of essential metal ions, i.e. $\mathrm{Zn}$ (II) and $\mathrm{Cu}(\mathrm{I})$, to participate in metal ion detoxification of, for example, $\mathrm{Cd}(\mathrm{II})$ and $\mathrm{Hg}(\mathrm{II})$, and to function in the direct scavenging of cell damaging reactive oxygen species $\left({ }^{\circ} \mathrm{OH}\right.$ and $\mathrm{O}^{2 \cdot}$ ) leading to disulfide bridge formation between Cys residues.[6] For a long time and based on the vertebrate MTs, which were the first MTs discovered,[7] it was assumed that only Cys thiolate groups can serve as ligands in these metal cluster. However, recently more and more data show that also histidine residues, which are found in some MT sequences from diverse species, 
participate in metal ion coordination through their imidazole nitrogen atoms.[8-12] This naturally raises the fundamental question regarding the criteria governing the exclusive use of Cys as coordinating residues in most MTs versus the additional recruitment of His residues in others.

Only two of these His containing MT sequences were structurally characterized with NMR spectroscopy so far, the bacterial SmtA MT from Synechococcus elongatus PCC 7942 and the plant MT E $\mathrm{E}_{\mathrm{c}}-1$ from Triticum aestivum (common bread wheat).[9,12] In SmtA the arrangement of the single $\mathrm{Zn}_{4} \mathrm{Cys}_{9} \mathrm{His}_{2}$ cluster is similar to the one observed in the $\alpha$-domain of vertebrate MTs $\left(\mathrm{Zn}_{4} \mathrm{Cys}_{11}\right)$ but with exchange of two of the terminally coordinating Cys residues by His. Replacement of either of the two His by Cys destabilizes the protein fold and reduces the binding affinity for $\mathrm{Zn}(\mathrm{II})$.[13] Possible reasons for this might be an increased electrostatic repulsion due to the additional negative charges introduced by the His-to-Cys mutation (His is a charge-neutral ligand, while the Cys thiolate groups are negatively charged) or steric effects due to the different size and geometry of the His versus the Cys ligand. For the opposite case, i.e. the replacement of Cys by His residues in a vertebrate MT, small structural changes were observed, while the $\mathrm{Zn}$ (II) and $\mathrm{Cd}(\mathrm{II})$ binding capacity and also the binding affinity of $\mathrm{Cd}(\mathrm{II})$ ions was preserved.[14]

The second structurally characterized His-containing MT, the wheat $\mathrm{E}_{\mathrm{c}}-1$ protein, is exclusively expressed in the reproductive parts such as pollen and embryos and was isolated from wheat germs in its $\mathrm{Zn}$ (II)-bound form.[15] Considering that the reproductive parts are generally most sensitive to any kind of damage, also tight control of metal ion transport, including $\mathrm{Zn}(\mathrm{II})$ and $\mathrm{Cd}(\mathrm{II})$, is highly important. Wheat $\mathrm{E}_{\mathrm{c}}-1$ and especially its larger C-terminal domain, denoted as $\beta_{\mathrm{E}}$-domain, has a very peculiar structure unprecedented by any other MT structure known so far. The $\beta_{\mathrm{E}}$-domain contains a $\mathrm{ZnCys}_{2} \mathrm{His}_{2}$ binding site next to a $\mathrm{Zn}_{3} \mathrm{Cys}_{9}$ cluster, however, the precise function of this $\mathrm{Zn}$-finger like site is still mysterious. Based on Histo-Cys mutations it has been concluded that the isolated $\mathrm{Cys}_{2} \mathrm{His}_{2}$ binding site is crucial to ensure correct domain folding only in presence of $\mathrm{Zn}(\mathrm{II})$, which again might point to a crucial role in $\mathrm{Zn}$ (II) homeostasis including discrimination against toxic $\mathrm{Cd}(\mathrm{II})$ ions.[16]

Generally, mixed Cys and His coordination of $\mathrm{Zn}(\mathrm{II})$ is a common feature observed in zincfinger proteins, and some insights into the thermodynamic implications of His versus Cys coordination of $\mathrm{Zn}$ (II) in proteins come from a detailed study on a consensus zinc finger peptide by Berg and coworkers.[17] In this specific Zn-finger motif the variation of ligands, i.e. Cys and His, has only little effect on the Zn(II) affinity (approximately a 2-fold affinity increase per Cys 
residue), whereas the differences in $\mathrm{Cd}(\mathrm{II})$ affinities were substantial, i.e. an increase of roughly two orders of magnitude for each Cys residue introduced. In direct comparison, the $\mathrm{Zn}$ (II) affinity to the $\mathrm{Cys}_{2} \mathrm{His}_{2}$ site was found to be higher than the $\mathrm{Cd}(\mathrm{II})$ affinity by a factor of 350 , while $\mathrm{Cd}(\mathrm{II})$ coordination to the $\mathrm{Cys}_{3} \mathrm{His}$ and $\mathrm{Cys}_{4}$ sites was preferred by a factor of 2 and 28 , respectively. This means that $\mathrm{Cys}_{4}$ sites show a clear preference for $\mathrm{Cd}(\mathrm{II})$ over $\mathrm{Zn}(\mathrm{II})$, whilst $\mathrm{Cys}_{2} \mathrm{His}_{2}$ sites favor $\mathrm{Zn}(\mathrm{II})$ coordination, which is both in accordance with the HSAB principle introduced by Pearson.[18] $\mathrm{Cys}_{3} \mathrm{His}$ sites have a similar affinity for either metal ion.

The second domain of the $\mathrm{E}_{\mathrm{c}}-1$ protein, the $\mathrm{N}$-terminal $\gamma$-domain, hosts a $\mathrm{M}_{2}^{\mathrm{II}} \mathrm{Cys}_{6}$ cluster and hence the smallest metal-thiolate cluster that can be formed with divalent metal ions.[19,20] The solution structures of $\mathrm{Zn}_{2^{-}}$as well as $\mathrm{Cd}_{2} \gamma-\mathrm{E}_{\mathrm{c}^{-}}-1$ were determined recently in our group with NMR spectroscopy and hence provide an ideal basis to extend the investigation of Cys/His mutations to a small metal cluster, especially with respect to the metal ion binding properties, the $\mathrm{Zn}(\mathrm{II})$-to-Cd(II) exchange process, and ideally also to the structural impact of the mutation.

\section{Materials and Methods}

\subsection{Materials}

Cadmium acetate, zinc acetate, and ammonium acetate were from Fluka (Buchs, Switzerland), tris(hydroxymethyl)-aminomethan- $\mathrm{d}_{11}$ (Tris- $\mathrm{d}_{11}$ ) from Euriso-top (France), $\mathrm{D}_{2} \mathrm{O}$ from Armar

Chem. (Switzerland), ${ }^{113} \mathrm{CdCl}_{2}$ from Cambridge Isotope Laboratories (Reseachem, Switzerland), and Chelex ${ }^{\circledR} 100$ resin from Bio-Rad (Switzerland). All other chemicals were ACS grade from Sigma-Aldrich Chemie (Buchs, Switzerland). All solutions were prepared with deionized water. When necessary, water was vacuum-degassed and nitrogen-saturated to exclude molecular oxygen.

\subsection{Generation of the $\mathrm{Cl} 4 \mathrm{H}$ and $\mathrm{C} 2 \mathrm{OH}$ mutants}

The pGEX expression system based plasmid encoding a GST- (glutathione S-transferase-) tagged $\gamma-\mathrm{E}_{\mathrm{c}}-1$ form was previously cloned in our group and used as a template for site-directed mutagenesis.[19] Using the primers 5'-TGC CGT GCC GCA CCC CGG CGG-3' (forward) and 5'-CCG CCG GGG TGC GGC ACG GCA-3' (reverse) as well as 5'-GGC GGC ACG GGC CAT AGA TGC ACC TC-3' (forward) and 5'-GAG GTG CAT CTA TGG CCC GTG CCG CC3' (reverse) linear plasmids containing the $\mathrm{C} 14 \mathrm{H}$ and $\mathrm{C} 20 \mathrm{H}$ mutation, respectively, were 
obtained. After digestion of the original dam methylated template plasmid with DpnI,[21] the polymerase chain reaction (PCR) mixture was used for transformation of Escherichia coli DH5 $\alpha$ cells. Subsequently, plasmids were isolated from the obtained colonies, sequenced, and the desired mutation carrying plasmids transformed into E. coli BL21 cells for expression. Expression and purification of the $\mathrm{C} 14 \mathrm{H}-\gamma-\mathrm{E}_{\mathrm{c}}-1$ and $\mathrm{C} 20 \mathrm{H}-\gamma-\mathrm{E}_{\mathrm{c}}-1$ mutants was performed as for the wild-type domain.[19]

\subsection{Reconstitution of metal loaded forms}

To obtain the metal-loaded forms of the two $\gamma-\mathrm{E}_{\mathrm{c}}-1$ mutants, three equivalents of $\mathrm{Zn}$ (II) or $\mathrm{Cd}(\mathrm{II})$ were added to the reduced apo-forms in $0.01 \mathrm{M} \mathrm{HCl}$. Subsequently, the $\mathrm{pH}$ was adjusted to 7.5-8.0 in a buffer containing either $10 \mathrm{mM}$ ammonium acetate for measurements with mass spectrometry (MS) or $10 \mathrm{mM}$ Tris- $\mathrm{HCl}$ and $10 \mathrm{mM} \mathrm{NaCl}$ for spectroscopic characterizations. The excess of metal ions was removed either by size-exclusion chromatography (SEC, Superdex Peptide 10/300 GL, GE HealthCare, Glattbrugg, Switzerland) using the same buffer for elution or by dialysis using a Tube-O-Dialyzer ${ }^{\mathrm{TM}}$ device with a molecular weight cut-off of $1 \mathrm{kDa}$ (GBiosciences, Socochim SA, Savigny, Switzerland).

\subsection{Protein and metal ion quantification}

Protein concentrations were determined based on the quantification of thiolate groups with the 2,2'-dithiodipyridine (2-PDS) assay assuming the presence of five reduced Cys residues in each mutant.[22] No oxidation was observed under the conditions applied as verified with mass spectrometry (see Supplementary Information).Metal ion concentrations were measured with flame atomic absorption spectroscopy (F-AAS) in $0.2 \mathrm{M} \mathrm{HNO}_{3}$ using an AA240FS spectrometer (Agilent Technologies, Basel, Switzerland).

\subsection{Metal ion titrations}

All titration experiments were performed under strictly anaerobic conditions in a Type B Vinyl Anaerobic Chamber (Coy Lab, USA) equipped with a palladium catalyst and operated with a 5\% hydrogen/95\% nitrogen gas mix or by using a septum-sealed spectrophotometric cuvette. $\mathrm{ZnCl}_{2}$ and $\mathrm{CdCl}_{2}$ solutions were prepared using deoxygenized water and exact concentrations determined with F-AAS. For each titration experiment these stock solutions were diluted to make 
$4 \mu \mathrm{L}$ of the solution equal to 1 equivalent of metal ion per protein molecule in the respective apo-protein solution. For the titrations, increasing amounts of $\mathrm{Zn}(\mathrm{II})$ or $\mathrm{Cd}(\mathrm{II})$ were added to approximately $20 \mu \mathrm{M}$ apo- or $\mathrm{Zn}_{2} \gamma-\mathrm{E}_{\mathrm{c}}-1$ mutant solutions $(700 \mu \mathrm{L})$ in a buffer containing $10 \mathrm{mM}$ Tris-HCl, $10 \mathrm{mM} \mathrm{NaCl}, \mathrm{pH}$ 7.5, using a micro-syringe (Hamilton, Bonaduz, Switzerland) filled within the anaerobic chamber and sealed with a paraffin layer. After each titration experiment, the final metal ion concentration was again measured by F-AAS and the protein concentration by the 2-PDS assay to exclude experimental errors and a possible oxidation of MTs during the titration.

\section{6. pH Titrations}

$700 \mu \mathrm{L}$ of a $20 \mu \mathrm{M}$ solution of the respective $\mathrm{Zn}_{2}$ - or $\mathrm{Cd}_{2} \gamma-\mathrm{E}_{\mathrm{c}}-1$ mutant were prepared in $10 \mathrm{mM}$ Tris- $\mathrm{HCl}, 10 \mathrm{mM} \mathrm{NaCl}, \mathrm{pH}$ 2, and transferred into a cuvette. The $\mathrm{pH}$ was increased with incremental amounts of diluted $\mathrm{NaOH}$ solutions $(0.01,0.1$, and $1 \mathrm{M})$ and UV spectra taken for each step. Plots of molar absorptivity at $230 \mathrm{~nm}$ for the respective $\mathrm{Zn}_{2}$ - and at $250 \mathrm{~nm}$ for the respective $\mathrm{Cd}_{2}$-form versus $\mathrm{pH}$ were fitted with the program Origin $8.0^{\circledR}$ (OriginLab, Northampton, MA, USA) considering a single apparent $\mathrm{p} K_{\mathrm{a}}$ value for all cysteine residues or two independent $\mathrm{p} K_{\mathrm{a}}$ values in the presence of the respective metal ion as described previously.[23]

\subsection{Mass spectrometry}

Samples of $\mathrm{Zn}_{2^{-}}, \mathrm{Cd}_{2^{-}}$, as well as mixed $\mathrm{Zn}_{1} \mathrm{Cd}_{1} \gamma-\mathrm{E}_{\mathrm{c}^{-}} 1$ forms of both mutants in $10 \mathrm{mM}$ ammonium acetate $\mathrm{pH} 7.5$ were diluted with $50 \% \mathrm{MeOH}$ and injected into a quadrupole time-offlight (TOF) Synapt G2 spectrometer (Waters, UK). Scans were accumulated and processed by the software MassLynx 3.5 (Micromass). $\mathrm{m} / \mathrm{z}$ spectra were deconvoluted using the maximum entropy algorithm (MaxEnt1 in MassLynx 3.5). Electrospray parameters were capillary 2.6 V, cone $50 \mathrm{~V}$, and source temperature $80{ }^{\circ} \mathrm{C}$.

\subsection{NMR spectroscopy}

NMR samples were prepared by reconstitution of the respective fully reduced apo-form mutant at $\mathrm{pH} 2$ with 2.1 equivalents of either ${ }^{113} \mathrm{CdCl}_{2}, \mathrm{ZnCl}_{2}$ or a mixture of both salts at a protein concentration below $40 \mu \mathrm{M}$ to prevent aggregation and dimer formation. Subsequently, the $\mathrm{pH}$ was raised to 7.5 with Tris- $\mathrm{d}_{11}$. Samples were concentrated using an Amicon stirred 
ultrafiltration cell (Millipore, Switzerland) and supplemented with $\mathrm{D}_{2} \mathrm{O}$ to a final concentration of $10 \%$. The final protein concentration was around $0.7-1.0 \mathrm{mM}$ and the volume $250 \mu \mathrm{L}$. All 2D NMR experiments were recorded at $310 \mathrm{~K}$ on a Bruker Avance $700-\mathrm{MHz}$ spectrometer, for

${ }^{113} \mathrm{Cd}-\mathrm{NMR}$ experiments a Bruker DRX 500-MHz spectrometer was used. The ${ }^{113} \mathrm{Cd}$ chemical shifts were directly referenced to an external $0.1 \mathrm{M} \mathrm{Cd}\left(\mathrm{ClO}_{4}\right)_{2}$ solution.

\section{Results and discussion}

\subsection{Design of Cys-to-His mutants}

In this project we aimed to generate novel forms of a small metal cluster by replacing one of the Cys residues in the $\gamma-\mathrm{E}_{\mathrm{c}}-1$ domain by His (Fig 1A). The structure of the wild-type domain was solved in our group before (PDB IDs: 2L61, 2L62) revealing a metal-thiolate cluster of the form $\mathrm{M}_{2}{ }_{2}{ }_{2} \mathrm{Cys}_{6}$ with four terminally coordinating Cys residues, i.e. coordination to one metal ion only, and two Cys as bridging ligands between the two metal ions (Fig. 1B). $\mathrm{Zn}$ (II)-to-Cd(II) exchange reactions have indicated that the $\mathrm{Zn}(\mathrm{II})$ ion coordinated by residues $\mathrm{C} 4, \mathrm{C} 10, \mathrm{C} 14$, and C20 is less readily replaced by a $\mathrm{Cd}(\mathrm{II})$ ion than the $\mathrm{Zn}$ (II) ion coordinated in the other position. [24] Accordingly, we aimed to mutate one of these residues to a His ligand to make this binding site even less prone for $\mathrm{Cd}(\mathrm{II})$ binding and to further increase the specificity of the two binding sites for different metal ions. As His was only observed as terminal ligand in MTs so far, only $\mathrm{C} 14$ and $\mathrm{C} 20$ remain for mutation. As both Cys reside in a loop structure, a mutation at these positions is expected to cause least distortion of the 3D structure.[19,25] 
(A)

WT GSGCDDKCGCAVPCPGGTGCRCTSAR

C14H GSGCDDKCGCAVPHPGGTGCRCTSAR

C20H GSGCDDKCGCAVPCPGGTGHRCTSAR

(B)

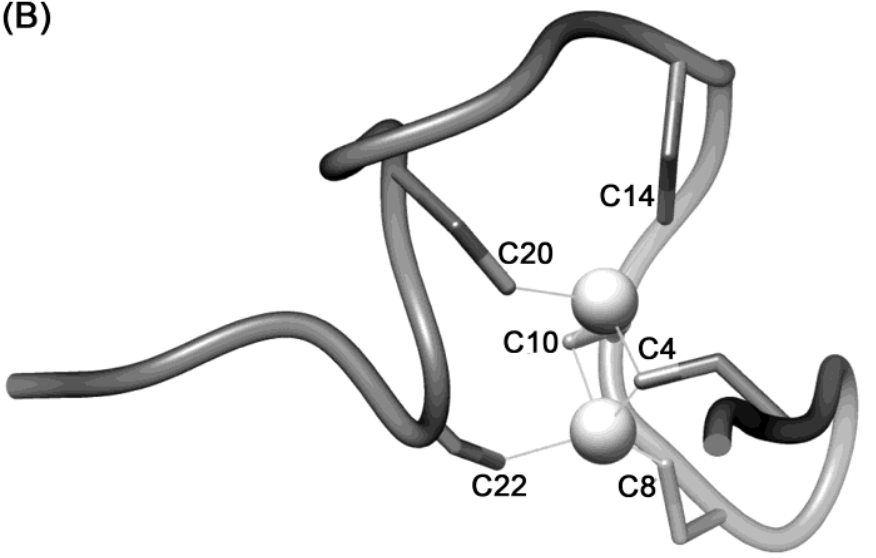

Fig. 1. (A) Amino acid sequences of the wild-type $\gamma-\mathrm{E}_{\mathrm{c}^{-}}-1$ domain and the two Cys-to-His mutants. (B) Solution structure of $\mathrm{Cd}_{2}-\gamma-\mathrm{E}_{\mathrm{c}^{-}} 1$ (PDB entry 2L61)[19] determined with NMR spectroscopy. Cys thiolate groups are shown in stick mode, coordinated $\mathrm{Cd}(\mathrm{II})$ ions as gray spheres, and the $\mathrm{Cd}(\mathrm{II})$-thiolate bonds as thin gray lines.

The two $\mathrm{C} 14 \mathrm{H}$ and $\mathrm{C} 20 \mathrm{H}$ mutants were generated from the wild-type $\gamma-\mathrm{E}_{\mathrm{c}}-1$ sequence cloned into the pGEX-4T vector. For this, the entire vector was amplified using two complementary primers for each mutation containing the desired mutation in the respective codon (Fig. S1). After verification by DNA sequencing, the respective plasmids were transformed into E. coli BL21 (DE3) cells for protein expression. The yields of purified $\mathrm{C} 14 \mathrm{H}-$ and $\mathrm{C} 20 \mathrm{H}-\gamma-\mathrm{E}_{\mathrm{c}}-1$ were 3.5-4.0 mg per $\mathrm{L}$ of cell culture and hence comparable to yields obtained for the wild-type form.

\subsection{Determination of the metal ion binding stoichiometry}

To ensure that the two mutants are still able to bind two metal ions as observed for the wildtype domain, 2.5 equivalents of $\mathrm{Zn}(\mathrm{II})$ or $\mathrm{Cd}(\mathrm{II})$ ions were added to the metal-free forms of $\mathrm{C} 14 \mathrm{H}-$ and $\mathrm{C} 20 \mathrm{H}-\gamma-\mathrm{E}_{\mathrm{c}}-1$ at $\mathrm{pH} 2$ followed by addition of $1 \mathrm{M}$ Tris to give a $10 \mathrm{mM}$ solution of $\mathrm{pH} 5$ and further $\mathrm{pH}$ adjustment with $1 \mathrm{M} \mathrm{NaOH}$ to a value of 8.0. Residual unbound metal ions were removed by incubation with Chelex ${ }^{\circledR} 100$ resin. The results are summarized in Table 1 . 
Table 1. Metal-binding ability of the $\mathrm{C} 14 \mathrm{H}-$ and $\mathrm{C} 20 \mathrm{H}-\gamma-\mathrm{E}_{\mathrm{c}}-1$ mutants. Metal ion concentrations were measured by F-AAS after incubation with Chelex ${ }^{\circledR} 100$ resin, protein concentrations were calculated based on the SH group contents measured with the 2-PDS assay.

\begin{tabular}{|c|c|c|c|c|}
\hline & \multicolumn{2}{|c|}{$\mathrm{C} 14 \mathrm{H}-\gamma-\mathrm{E}_{\mathrm{c}}-1$} & \multicolumn{2}{c|}{$\mathrm{C} 20 \mathrm{H}-\gamma-\mathrm{E}_{\mathrm{c}}-1$} \\
\hline & $\mathrm{Zn}(\mathrm{II})$-form & $\mathrm{Cd}(\mathrm{II})$-form & $\mathrm{Zn}$ (II)-form & Cd(II)-form \\
\hline$\left[\gamma-\mathrm{E}_{\mathrm{c}}-1\right] / \mu \mathrm{M}$ & 10.3 & 10.3 & 11.4 & 12.1 \\
\hline$\left[\mathrm{M}^{\mathrm{II}}\right] / \mu \mathrm{M}$ & 5.9 & 9.1 & 21.6 & 21.8 \\
\hline$\left[\mathrm{M}^{\mathrm{II}}\right] /\left[\gamma-\mathrm{E}_{\mathrm{c}}-1\right]$ & 0.7 & 1.0 & 1.9 & 1.8 \\
\hline
\end{tabular}

As apparent from the data in Table 1, the $\mathrm{C} 14 \mathrm{H}$ mutant has a lower metal ion binding capacity, i.e. only approximately one metal ion equivalent is bound. Even lower metal ion stoichiometries are observed for the $\mathrm{Cd}$ (II)-form of this mutant when SEC is used to remove the excess of unbound metal ions, i.e. 0.7 equivalents for the $\mathrm{Zn}(\mathrm{II})$ - and 0.5 equivalents for the Cd(II)-form. Probable explanations for the decreased binding ability are a distortion of the cluster structure due to the larger size of the His residue or an unfavorable position of the ligand for metal ion binding. Based on these results the $\mathrm{C} 14 \mathrm{H}-\gamma-\mathrm{E}_{\mathrm{c}}-1$ mutant was not further evaluated.

The $\mathrm{C} 20 \mathrm{H}-\gamma-\mathrm{E}_{\mathrm{c}}-1$ mutant, however, is able to form stable oxygen insensitive $\mathrm{Zn}_{2}$ and $\mathrm{Cd}_{2-}$ species. Due to the slightly lower than expected binding stoichiometries, dialysis was used as an alternative softer approach to remove the unbound metal ion excess in the further experiments yielding metal ion-to-protein stoichiometries of 2.

\section{3. $p H$ Stability of metal-thiolate clusters}

The cluster stability of the $\mathrm{C} 20 \mathrm{H}$ mutant was investigated by determining the apparent $\mathrm{p} K_{\mathrm{a}}$ values of the Cys residues in presence of metal ions and compared to the $\mathrm{p} K_{\mathrm{a}}$ values of the respective wild-type forms. For this, $\mathrm{pH}$ titration experiments were performed and the metal ion release was followed via the absorbance decrease of the ligand-to-metal charge transfer (LMCT) bands at 250 and $230 \mathrm{~nm}$ for the $\mathrm{Cd}(\mathrm{II})$ - and $\mathrm{Zn}$ (II)-species, respectively, with decreasing $\mathrm{pH}$ of the solution. The plots of absorbance against $\mathrm{pH}$ were fitted with two equations that consider either one common (Eq. 1) or two different apparent $\mathrm{p} K_{\mathrm{a}}$ values (Eq. 2) (Fig. 2, Table S1). However, in contrast to the $\mathrm{pH}$ titration of the wild-type domain, data fitting with Eq. 2 did not 
improve the results for the $\mathrm{C} 20 \mathrm{H}$ mutant, especially with regard to the $\mathrm{p} K_{\mathrm{a}}$ value of the main titration step. The $\mathrm{p} K_{\mathrm{a}}$ values are depicted in Fig. $2 \mathrm{C}$ and the complete curve fitting parameters as well as the equations used are given in the supplementary information (Table S1). As discussed previously, the two metal ion binding sites in the wild-type domain have distinctively different $\mathrm{p} K_{\mathrm{a}}$ values and the lower $\mathrm{p} K_{\mathrm{a}}$ value was assigned to the metal ion binding site formed by residues C4, C10, C14, and C20 (indicated as I in Fig. 2C).[19,24] However, the C20H mutation seems to destabilize this binding site in such a way that its $\mathrm{p} K_{\mathrm{a}}$ value both in the $\mathrm{Zn}(\mathrm{II})$ - and in the $\mathrm{Cd}(\mathrm{II})$ form is increased close to the value of the second metal ion binding site, the latter being virtually unaffected by the mutation. As a consequence, a data fit considering just one common apparent $\mathrm{p} K_{\mathrm{a}}$ value for both sites is sufficient to describe the system. 

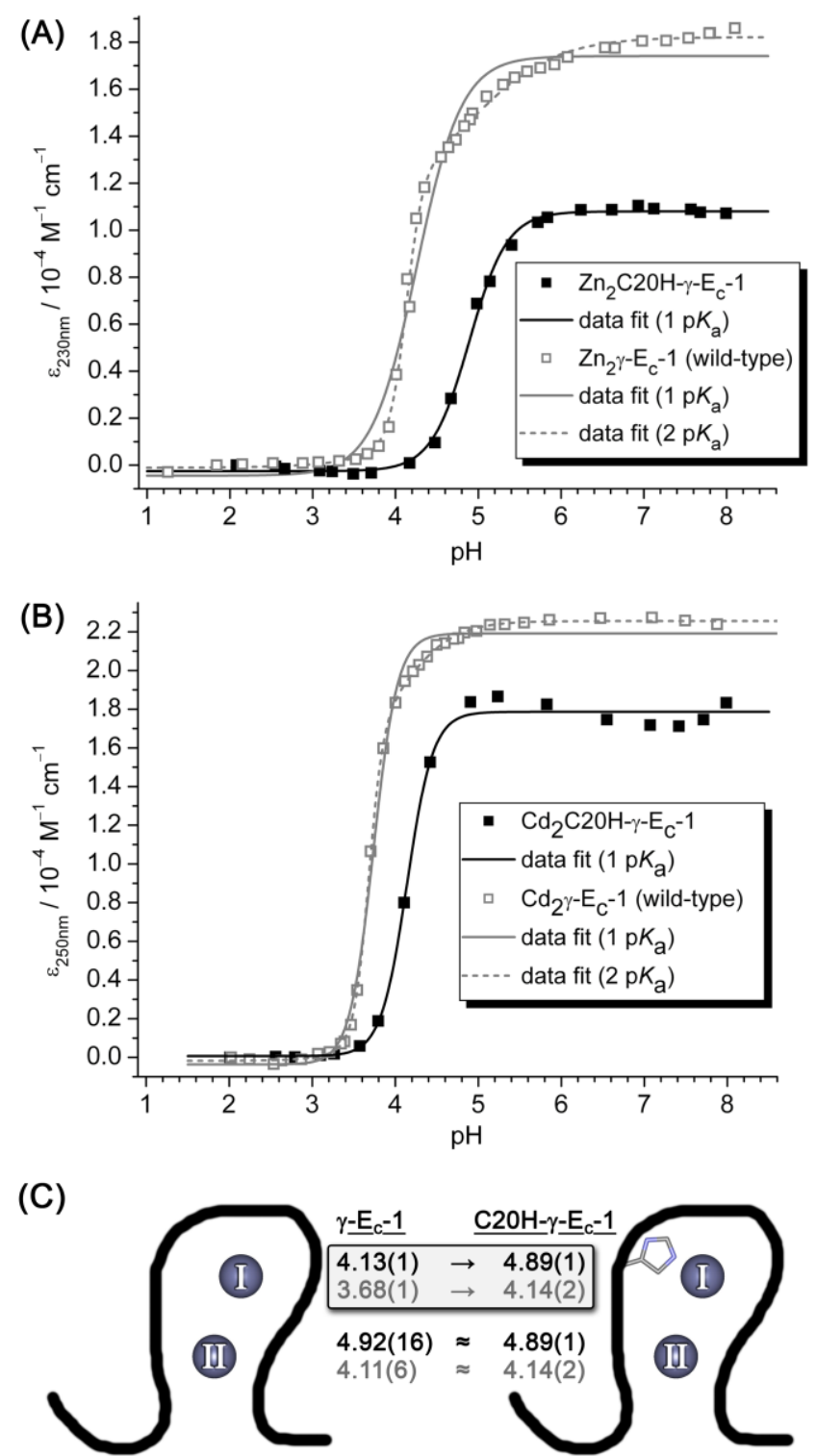

Fig. 2 Plots of molar absorptivity against $\mathrm{pH}$ values for the $\mathrm{pH}$ titrations of $(\mathbf{A})$ the $\mathrm{Zn}_{2}$ - and (B) the $\mathrm{Cd}_{2}$-forms of $\mathrm{C} 20 \mathrm{H}$ - (black squares) and wild-type $\gamma$ - $\mathrm{E}_{\mathrm{c}^{-}}-1$ (grey open squares). The data fits using equation 1 are shown as solid lines, the data fits using equation 2 and hence assuming two $\mathrm{p} K_{\mathrm{a}}$ values are shown as dashed lines. $(\mathbf{C})$ Scheme of wild-type $\gamma-\mathrm{E}_{\mathrm{c}}-1$ (left) and its $\mathrm{C} 20 \mathrm{H}$ mutant (right) with the position of His20 indicated. The values shown are the apparent $\mathrm{p} K_{\mathrm{a}}$ values (in black for the $\mathrm{Zn}(\mathrm{II})$, in grey for the $\mathrm{Cd}(\mathrm{II})$-form, standard deviations given in brackets) as 
determined from the plots in $(\mathbf{A}, \mathbf{B})$ using an equation considering a single $\mathrm{p} K_{\mathrm{a}}$ value (Eq. 1, values for $\left.\mathrm{C} 20 \mathrm{H}-\gamma-\mathrm{E}_{\mathrm{c}}-1\right)$ or two different $\mathrm{p} K_{\mathrm{a}}$ values (Eq. 2, values for wild-type $\left.\gamma-\mathrm{E}_{\mathrm{c}}-1\right)$.

\subsection{Zn(II) to Cd(II) ion exchange monitored by UV spectroscopy}

In order to evaluate the preferred site of $\mathrm{Cd}(\mathrm{II})$ incorporation and at the same time the preferred site of $\mathrm{Zn}(\mathrm{II})$ binding, $\mathrm{Zn}_{2} \mathrm{C} 20 \mathrm{H}-\gamma-\mathrm{E}_{\mathrm{c}}-1$ was titrated with $\mathrm{Cd}(\mathrm{II})$ at a $\mathrm{pH}$ value close to physiological conditions, i.e. 7.5, and the evolution of the LMCT band at $250 \mathrm{~nm}$ was monitored by UV spectroscopy. Results are compared with the titration of the wild-type $\gamma-E_{c}-1$ domain and depicted in Fig. 3. The addition of Cd(II) ions leads to an absorptivity increase at $250 \mathrm{~nm}$ (Fig. 3A), which is virtually identical for both forms up to approximately 1 equiv. of Cd(II) (Fig. 3B). Addition of higher amounts leads to a lower increase for the mutant compared to the wild-type. This observation perfectly fits a model, which assumes coordination of the first $\mathrm{Cd}(\mathrm{II})$ equivalent to binding site II (see Fig. 2C) and hence formation of a $\mathrm{CdCys}_{4}$ site in both species. The second $\mathrm{Cd}(\mathrm{II})$ ion is then coordinated to site I, which provides another $\mathrm{Cys}_{4}$ or a $\mathrm{Cys}_{3} \mathrm{His}$ coordination environment in wild-type or $\mathrm{C} 20 \mathrm{H}-\gamma-\mathrm{E}_{\mathrm{c}}-1$, respectively, and accordingly the absorptivity increase is distinctively larger in the wild-type domain than in the mutant. After addition of approximately two equiv. of $\mathrm{Cd}(\mathrm{II}), \varepsilon_{250 \mathrm{~nm}}$ remains constant in both species, corroborating the preserved metal ion binding capacity in the mutant already seen from the analytical data (Table 1). This interpretation is corroborated by the difference UV spectra obtained by subtracting the respective spectra for ( $n-1)$ equivalents $\mathrm{Cd}(\mathrm{II})$ from the one measured for $\mathrm{n}$ equivalents of $\mathrm{Cd}(\mathrm{II})$ (Fig. 3C). Also here the difference spectra for the first equivalent of $\mathrm{Cd}(\mathrm{II})$, i.e. the spectra of 0 equiv. $\mathrm{Cd}(\mathrm{II})$ added subtracted from the spectrum of 1 equiv. $\mathrm{Cd}(\mathrm{II})$ added, give closely similar

$\varepsilon_{250 \mathrm{~nm}}$ values for both wild-type $\gamma-\mathrm{E}_{\mathrm{c}}-1$ and the mutant. The second spectra, i.e. 2-1 equiv. of $\mathrm{Cd}(\mathrm{II})$, shows again clearly the smaller absorptivity increase already seen for $\varepsilon_{250 \mathrm{~nm}}$ in Fig. $3 \mathrm{~B}$ that is based on the Cys-to-His replacement in the mutant. 

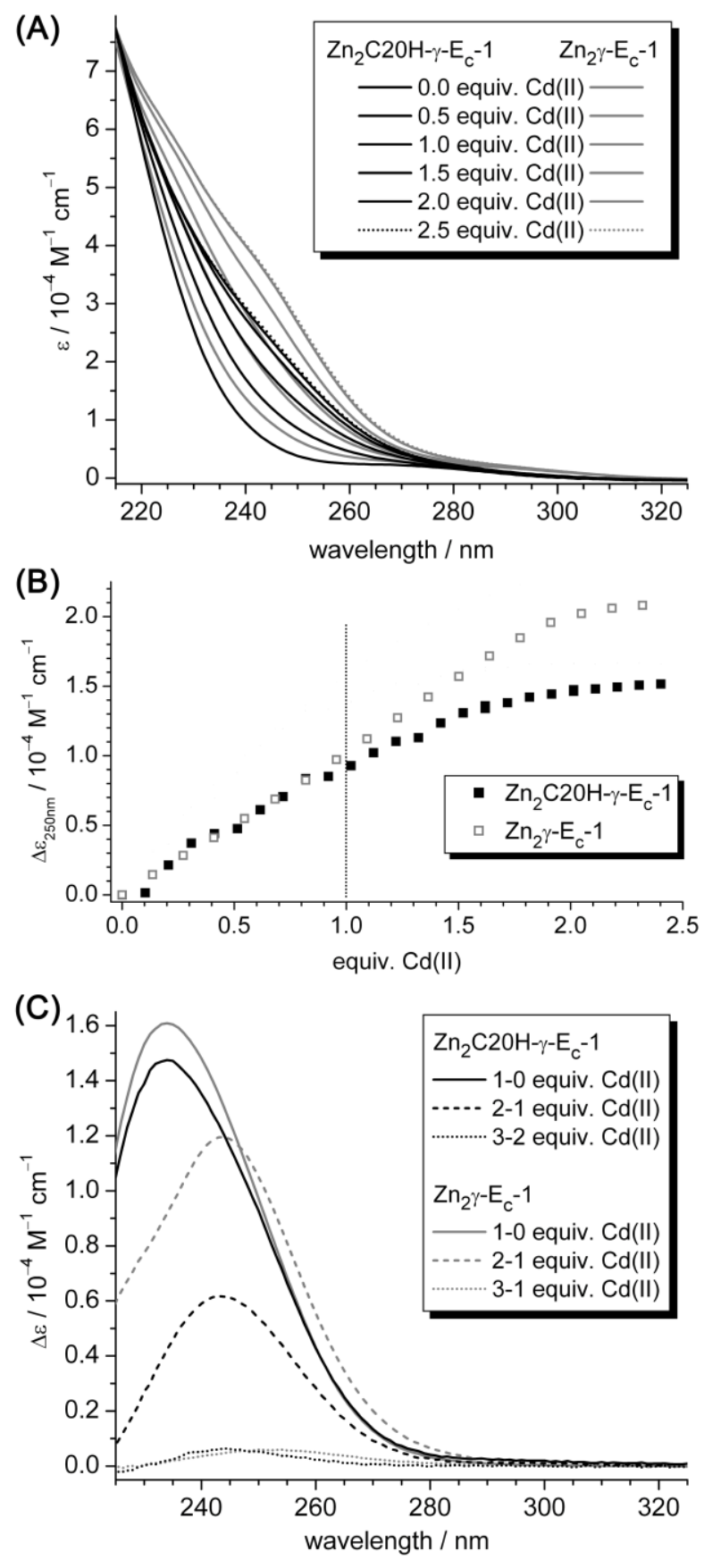

Fig. 3 Comparison of Zn(II)-to-Cd(II) titrations followed by UV spectroscopy for wild-type $\gamma$ $\mathrm{E}_{\mathrm{c}}-1$ (grey) and its $\mathrm{C} 20 \mathrm{H}$ mutant (black). (A) UV spectra. After addition of 2.0 equiv. $\mathrm{Cd}(\mathrm{II})$ spectra remain unchanged (dotted lines). (B) Plots of $\varepsilon_{250 \mathrm{~nm}}$ against the equiv. of added $\mathrm{Cd}(\mathrm{II})$ ions. For better comparison, the $\varepsilon_{250 \mathrm{~nm}}$ values for $\mathrm{Zn}_{2} \gamma-\mathrm{E}_{\mathrm{c}}-1$ and $\mathrm{Zn}_{2} \mathrm{C} 20 \mathrm{H}-\gamma-\mathrm{E}_{\mathrm{c}}-1$, respectively, 
were subtracted from all successive values. Addition of 1 equiv. $\mathrm{Cd}(\mathrm{II})$ is highlighted with a vertical dotted line. (C) Difference spectra to illustrate spectral changes upon Cd(II) addition (see text).

Closer inspection of the $\varepsilon_{250 \mathrm{~nm}}$ values and the curve progression in Fig. $3 \mathrm{~B}$ allows a rough estimation of the ratio between the different species formed, i.e. $\mathrm{Zn}_{2^{-}}: \mathrm{ZnCd}-: \mathrm{Cd}_{2}$-species, after the addition of one equiv. of $\mathrm{Cd}(\mathrm{II})$ to a solution of $\mathrm{Zn}_{2} \mathrm{C} 20 \mathrm{H}-\gamma-\mathrm{E}_{\mathrm{c}}-1$. Generally, equal binding affinities of $\mathrm{Cd}(\mathrm{II})$, or $\mathrm{Zn}(\mathrm{II})$, to either binding site in $\mathrm{C} 10 \mathrm{H}-\gamma-\mathrm{E}_{\mathrm{c}}-1$ should result in a purely statistical species distribution of $0.25: 0.50: 0.25$. However, it is already obvious from the discussion above that the fraction for the mixed $\mathrm{ZnCdC} 20 \mathrm{H}-\gamma-\mathrm{E}_{\mathrm{c}}-1$ must be higher. Presuming that the first $\mathrm{Cd}(\mathrm{II})$ ion is coordinated in site II (i.e. in a $\mathrm{CdCys}_{4}$ environment as corroborated by the NMR measurements discussed in Section 3.6), the $\varepsilon_{250 \mathrm{~nm}}$ value of the $\mathrm{ZnCdC} 20 \mathrm{H}-\gamma-\mathrm{E}_{\mathrm{c}}-1$ species should be equal to the $\varepsilon_{250 \mathrm{~nm}}$ value obtained after addition of one $\mathrm{Cd}(\mathrm{II})$ equivalent to wild-type $\mathrm{Zn}_{2} \gamma-\mathrm{E}_{\mathrm{c}}-1\left(9713 \mathrm{M}^{-1} \mathrm{~cm}^{-1}\right)$ or alternatively to half of the $\varepsilon_{250 \mathrm{~nm}}$ value of wild-type $\mathrm{Cd}_{2} \gamma$ $\mathrm{E}_{\mathrm{c}}-1\left(10402 \mathrm{M}^{-1} \mathrm{~cm}^{-1}\right)$. Accordingly, the statistical species distribution of $0.25: 0.50: 0.25$ would result in $\varepsilon_{250 \mathrm{~nm}}$ values of $8626 \mathrm{M}^{-1} \mathrm{~cm}^{-1}$ or alternatively $8970 \mathrm{M}^{-1} \mathrm{~cm}^{-1}$ (for the precise calculation see the Supplementary Information) and hence to obviously distinctively lower values than the actual observed extinction of $9276 \mathrm{M}^{-1} \mathrm{~cm}^{-1}$. A consensus between calculated and observed $\varepsilon_{250 \mathrm{~nm}}$ values is only reached assuming a ratio of $0.1: 0.8: 0.1$ (or alternatively $0.2: 0.6$ $: 0.2$ ). These results provide some indication that in addition to the different metal ion binding selectivities of the two sites I and II for $\mathrm{Zn}$ (II) and $\mathrm{Cd}(\mathrm{II})$ as deduced above, there seems to be also an increased stability of the mixed $\mathrm{ZnCd}$ species compared to the $\mathrm{Zn}_{2}$ and $\mathrm{Cd}_{2}$ species in the $\mathrm{C} 20 \mathrm{H}$ mutant. Certainly there is a high uncertainty of the calculated ratio as the $\varepsilon_{250 \mathrm{~nm}}$ value for the pure $\mathrm{ZnCd}-\mathrm{C} 20 \mathrm{H}-\gamma-\mathrm{E}_{\mathrm{c}}-1$ species is unknown.

At first glance, the results from the $\mathrm{pH}$ titration (Fig. 2C) and from the metal ion titration (Fig. 3) seem to contradict each other as on the one hand both binding sites have the same $\mathrm{p} K_{\mathrm{a}}$ values but on the other hand coordination of the first $\mathrm{Cd}(\mathrm{II})$ ion to the $\mathrm{C} 20 \mathrm{H}$ mutant seems to occur exclusively in a $\mathrm{CdCys}_{4}$ site. Nevertheless, it needs to be considered that structural changes can 
occur during the $\mathrm{pH}$ titration that can influence the metal ion binding affinities. Hence the results from the $\mathrm{pH}$ titration are not necessarily transferable to the situation at $\mathrm{pH}$ 7.5.

\subsection{Zn(II) to Cd(II) ion exchange monitored by mass spectrometry}

To further investigate the ratio of the formed species after addition of one equiv. of $\mathrm{Cd}(\mathrm{II})$ to the respective $\mathrm{Zn}_{2}$-forms, mass spectra were acquired (Fig. 4). The mass spectrum of the wildtype $\mathrm{Zn}_{2} \gamma-\mathrm{E}_{\mathrm{c}}-1$ form after addition of one equivalent of $\mathrm{Cd}(\mathrm{II})$ and after removal of unbound metal ions by dialysis shows three peaks assigned to the $\mathrm{Zn}_{2^{-}}, \mathrm{ZnCd}-$, and $\mathrm{Cd}_{2}$-species. The approximate ratio between these three species is $0.25: 0.50: 0.25$ (Fig. 4A). In contrast but in agreement with the calculations made above, the MS spectrum of $\mathrm{Zn}_{2} \mathrm{C} 2 \mathrm{OH}-\gamma-\mathrm{E}_{\mathrm{c}}-1$ after addition of one equiv. of $\mathrm{Cd}(\mathrm{II})$ shows a clearly reduced amount of the two homometallic species and the mixed $\mathrm{ZnCd}$-form as the major product (Fig. 4B).
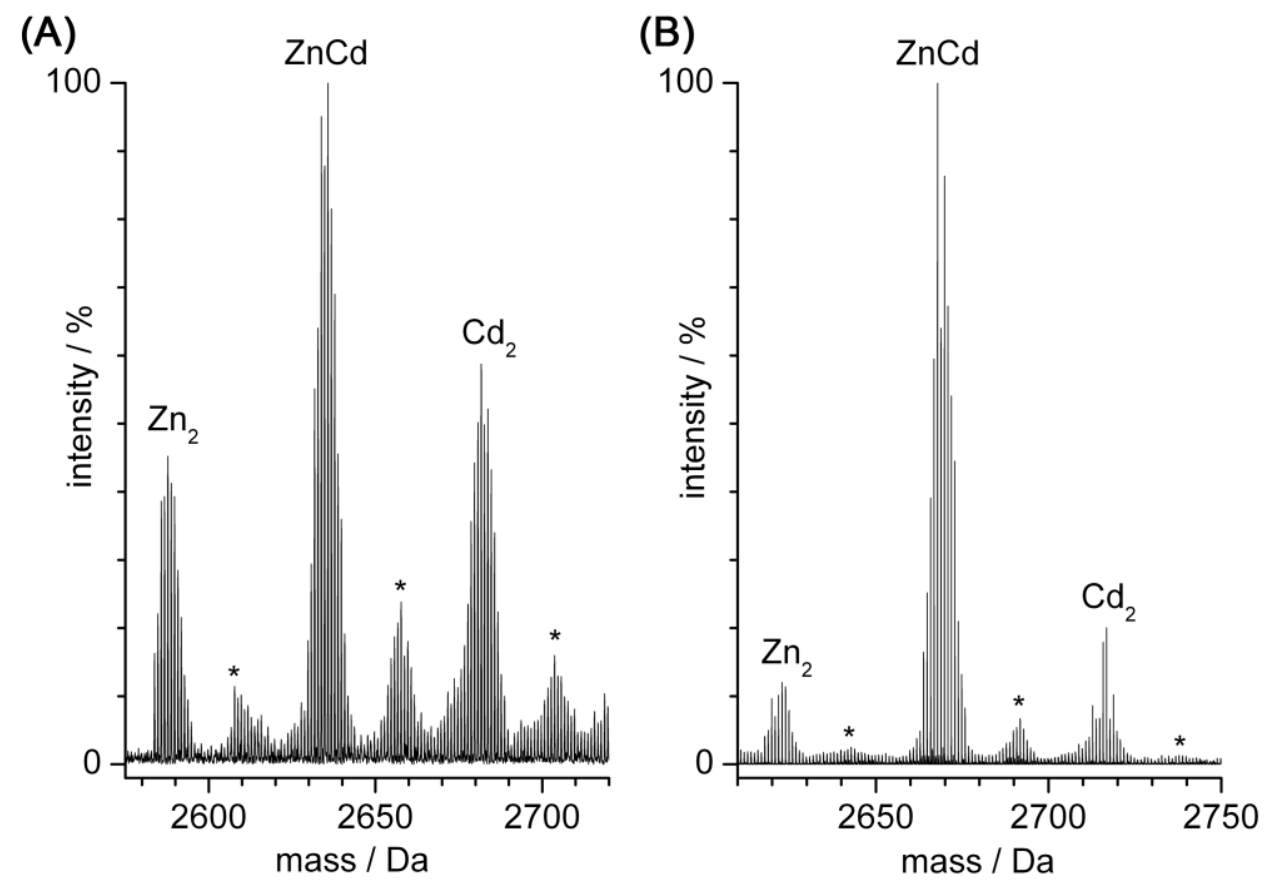

Fig. 4 Deconvoluted ESI-MS spectra of (A) wild-type $\mathrm{Zn}_{2} \gamma-\mathrm{E}_{\mathrm{c}^{-}}-1$ and (B) $\mathrm{Zn}_{2} \mathrm{C} 2 \mathrm{OH}-\gamma-\mathrm{E}_{\mathrm{c}^{-}}-1$ after addition of one equivalent of $\mathrm{Cd}(\mathrm{II}) . \mathrm{Na}^{+}$adducts are indicated with *.

\subsection{Incorporation of $\mathrm{Cd}(\mathrm{II})$ into $\mathrm{Zn}_{2} \mathrm{C} 2 \mathrm{OH}-\gamma-E_{c^{-}}-1$ followed by NMR spectroscopy}

The 2D heteronuclear single quantum correlation (HSQC) spectra show the cross peaks between the ${ }^{15} \mathrm{~N}$ and ${ }^{1} \mathrm{H}_{\mathrm{N}}$ nuclei and hence the amount of the signals corresponds roughly to the 
number of amino acids in the protein sequence, if disregarding residues with $\mathrm{N}$-containing side chains and proline residues. This type of spectrum is often referred to being the fingerprint of a protein because it shows a unique pattern of signal chemical shift positions and can be used for comparison to deduce protein structure similarity.[26] The $\left[{ }^{15} \mathrm{~N},{ }^{1} \mathrm{H}\right]-\mathrm{HSQC}$ spectra for ${ }^{15} \mathrm{~N}$ labeled $\mathrm{ZnCdC} 20 \mathrm{H}$ - and wild-type $\mathrm{ZnCd}-\gamma-\mathrm{E}_{\mathrm{c}}-1$ are shown in Fig. 5. Apparently, a large number of cross peaks can be superimposed onto each other suggesting a rather similar fold of both proteins.

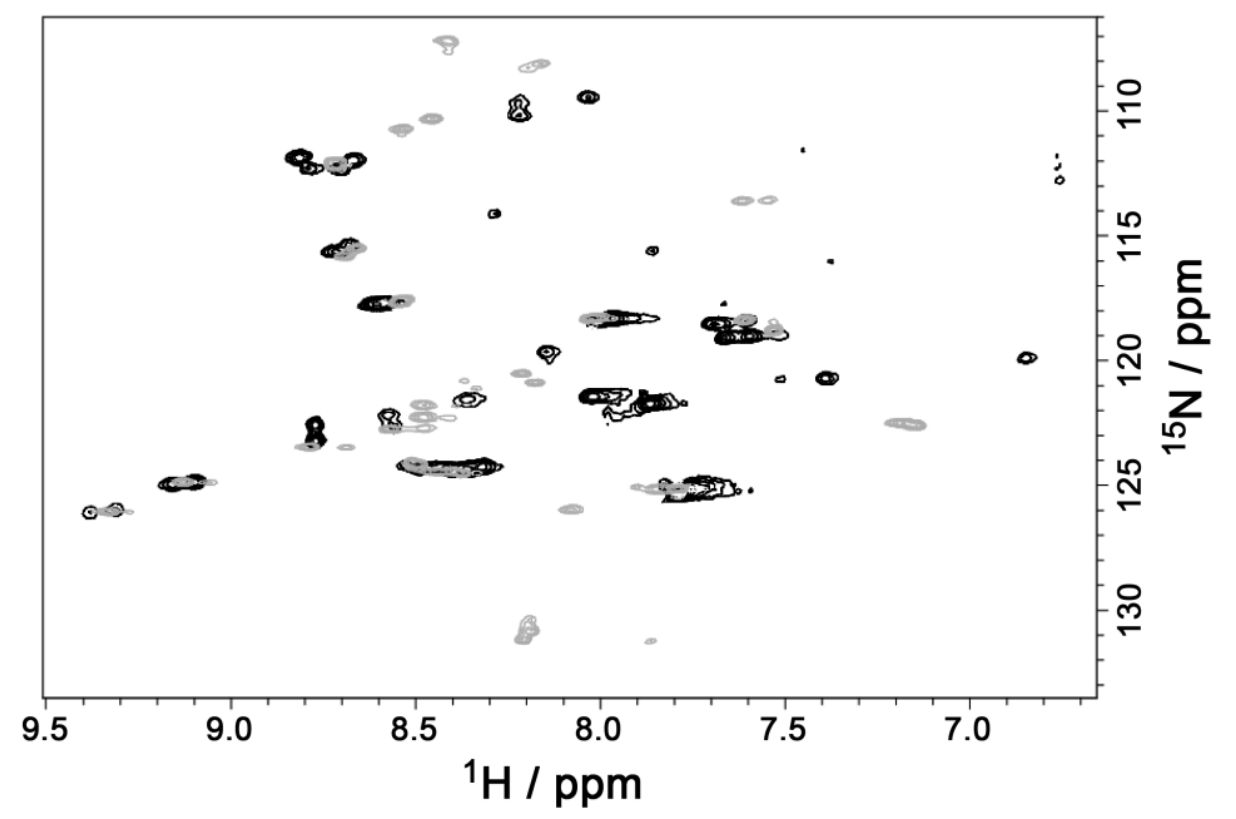

Fig. $5\left[{ }^{15} \mathrm{~N},{ }^{1} \mathrm{H}\right]$-HSQC spectra of the mixed $\mathrm{ZnCd}$-forms of wild-type $\gamma-\mathrm{E}_{\mathrm{c}}-1$ (grey) and the $\mathrm{C} 20 \mathrm{H}-\gamma-\mathrm{E}_{\mathrm{c}}-1$ mutant (black). A rather high degree of spectra overlap is observed.

Based on the results obtained with UV spectroscopy when observing the progression of the $\varepsilon_{250 \mathrm{~nm}}$ values in dependence of the amount of $\mathrm{Cd}(\mathrm{II})$ ions added, we already proposed that in the mixed $\mathrm{ZnCdC} 20 \mathrm{H}-\gamma-\mathrm{E}_{\mathrm{c}}-1$ species the $\mathrm{Zn}$ (II) ion is mainly bound to site I (Figs. 2C and 3B). Mass spectrometry in addition suggested that the mixed species is the major product when one equivalent of $\mathrm{Cd}(\mathrm{II})$ is added to a solution of $\mathrm{Zn}_{2} \mathrm{C} 20 \mathrm{H}-\gamma-\mathrm{E}_{\mathrm{c}}-1$ (Fig. 4B). To corroborate these results and to analyze the site specificity and species distribution further, $2 \mathrm{D}\left[{ }^{1} \mathrm{H},{ }^{1} \mathrm{H}\right]$-TOCSY (total correlation spectroscopy) spectra were recorded for both the wild-type and the $\mathrm{C} 2 \mathrm{OH}$ mutant (Fig. 6). 


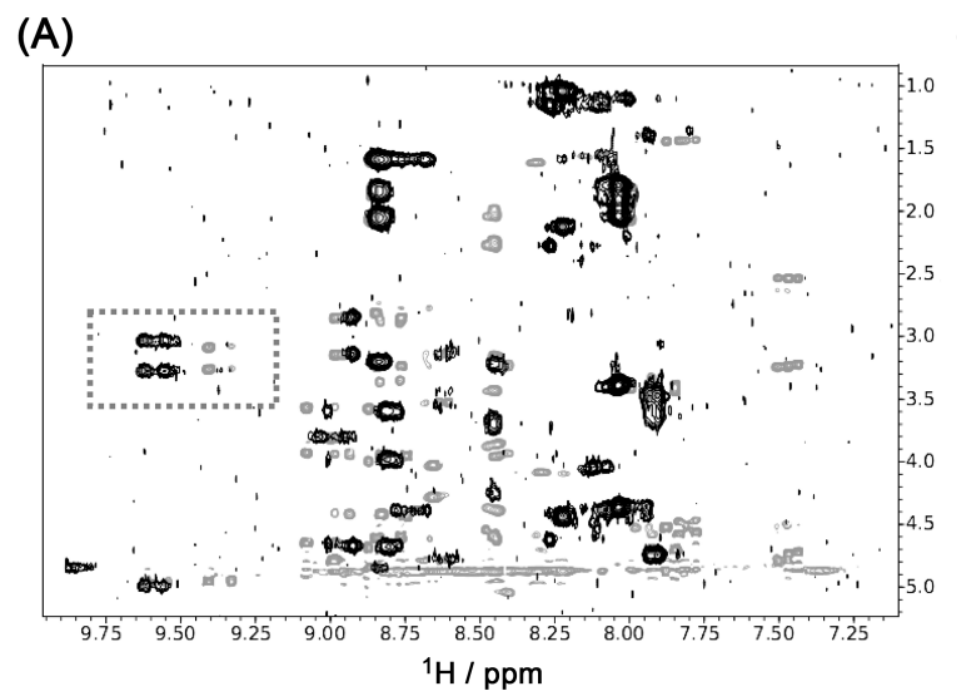

(B) site I: Zn Cd $\mathrm{Zn} \mathrm{Cd}$ site II: Cd Cd Zn Zn

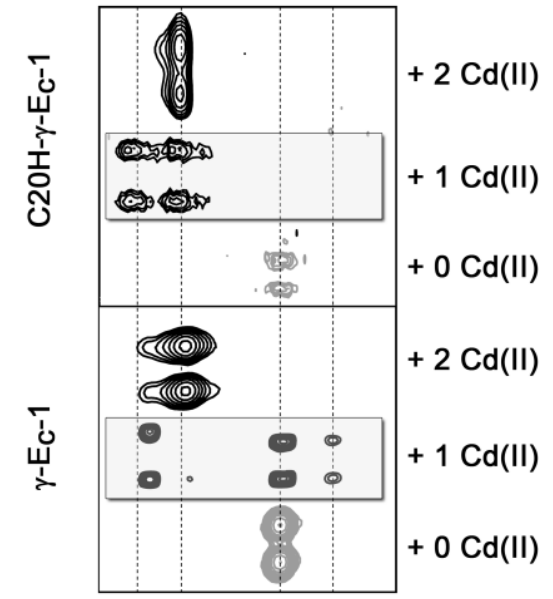

Fig. 6 (A) Overlay of $2 \mathrm{D}\left[{ }^{1} \mathrm{H},{ }^{1} \mathrm{H}\right]$-TOCSY $\left(\mathrm{H}_{\mathrm{N}}\right.$ region) spectra of solutions of $\mathrm{Zn}_{2} \gamma-\mathrm{E}_{\mathrm{c}}-1$ (grey) or $\mathrm{Zn}_{2} \mathrm{C} 20 \mathrm{H}-\gamma-\mathrm{E}_{\mathrm{c}}-1$ (black) after addition of one equiv. of $\mathrm{Cd}(\mathrm{II})$ ions. Characteristic signals of the Asp5 spin system are highlighted with a box. (B) Comparison of the chemical shifts of characteristic Asp5 spin $\mathrm{H}_{\beta} / \mathrm{H}_{\mathrm{N}}$ cross peaks obtained for the $\mathrm{C} 20 \mathrm{H}$ mutant (top three spectra slices) and wild-type $\gamma-\mathrm{E}_{\mathrm{c}}-1$ (bottom three spectra slices) after addition of 0,1 , or 2 equivalents of $\mathrm{Cd}(\mathrm{II})$ ions. The species assignment, i.e. the speciation of metal ions in the two different sites, is shown on top and based on the chemical shift of Asp5 observed in wild-type $\gamma$ - $E_{c}-1 .[19,24]$

Again the rather high degree of similarity between the two spectra indicates that the overall fold of wild-type $\gamma-\mathrm{E}_{\mathrm{c}}-1$ and the $\mathrm{C} 20 \mathrm{H}$ mutant is comparable. The lower amount of observed spin systems for $\mathrm{C} 20 \mathrm{H}-\gamma-\mathrm{E}_{\mathrm{c}}-1$ might be explained by a higher dynamic of the $\mathrm{C} 20 \mathrm{H}$ mutant structure rendering the further solution of the structure by NMR challenging. The chemical shift of the $\mathrm{H}_{\mathrm{N}}$ proton belonging to the Asp5 spin system is strongly dependent on the metal ion composition in $\gamma-\mathrm{E}_{\mathrm{c}}-1$, i.e. $9.42 \mathrm{ppm}$ for the $\mathrm{Zn}_{2^{-}}, 9.55 \mathrm{ppm}$ for the $\mathrm{Cd}_{2^{-}}$, and 9.63 and $9.33 \mathrm{ppm}$ for the mixed $\mathrm{ZnCd}-$ and $\mathrm{CdZn}$-forms, respectively, with the $\mathrm{ZnCd}$-form denoting the species in which the $\mathrm{Zn}(\mathrm{II})$ ion is coordinated in site I. Closely similar chemical shifts are observed for the signals in the respective spectra of the $\mathrm{Zn}_{2^{-}}, \mathrm{ZnCd}-$, and $\mathrm{Cd}_{2} \mathrm{C} 20 \mathrm{H}-\gamma-\mathrm{E}_{\mathrm{c}^{-}}-1$ forms. Intriguingly, after addition of one equiv. of $\mathrm{Cd}(\mathrm{II})$ the $\mathrm{C} 2 \mathrm{OH}-\gamma-\mathrm{E}_{\mathrm{c}}-1$ sample shows only signals corresponding to the $\mathrm{ZnCd}$ 
arrangement of metal ions (Fig. $6 \mathrm{~B}$ ) and hence the $\mathrm{Zn}$ (II) ion is exclusively coordinated to the His-containing binding site I.

The ${ }^{113} \mathrm{Cd}$ nucleus is often used to elucidate the number of nonequivalent $\mathrm{Cd}(\mathrm{II})$ ions as well as to predict the sort and number of ligands based on the chemical shift value. In the spectra of the mixed $\mathrm{ZnCdC} 20 \mathrm{H}-\gamma-\mathrm{E}_{\mathrm{c}}-1$ form only a single peak is detected (Fig. 7).

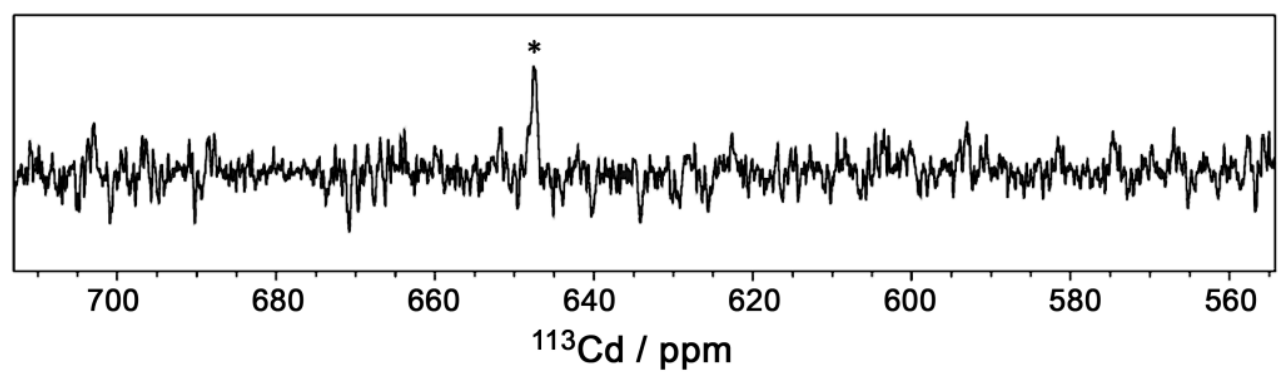

Fig. 7 1D ${ }^{113} \mathrm{Cd}$ NMR spectra of $\mathrm{ZnCdC} 20 \mathrm{H}-\gamma-\mathrm{E}_{\mathrm{c}}-1$. A single peak (indicated with *) with a chemical shift of 647 ppm is observed.

The chemical shift value of this signal indicates a tetrahedral tetrathiolate coordination sphere of the $\mathrm{Cd}(\mathrm{II})$ ion similar to the values observed before for the wild-type $\mathrm{Cd}_{2}-\gamma-\mathrm{E}_{\mathrm{c}}-1$ domain (661 and $659.5 \mathrm{ppm}$ ).[19] Participation of His in the coordination is expected to cause a distinct highfield shift of the signal compared to the value observed for the wild-type domain.[27] Previously reported values for $\mathrm{Cys}_{3} \mathrm{His}$ sites within a cluster structure are 596 and 567 ppm.[9] While the data support coordination of the $\mathrm{Cd}(\mathrm{II})$ ion in the $\mathrm{ZnCdC} 20 \mathrm{H}-\gamma-\mathrm{E}_{\mathrm{c}}-1$ species in the $\mathrm{Cys}_{4}$ site II, also a second signal for $\mathrm{Cd}$ in the $\mathrm{Cys}_{3} \mathrm{His}$ site I should be observed due to the additional presence of the $\mathrm{Cd}_{2}$ species in the sample as evident from Fig. 6B. Why this is not observed is not clear, but might be due to chemical exchange processes as observed before for the second domain of wheat $\mathrm{E}_{\mathrm{c}}-1 .[20]$

\section{Conclusion}

The objective of this investigation was to evaluate the influence of Cys-to-His mutations on the structure and metal ion binding abilities and selectivities of a small metal cluster forming domain from a plant metallothionein. Based on the well studied $\gamma-\mathrm{E}_{\mathrm{c}}-1$ domain from a wheat MT, the $\mathrm{C} 20 \mathrm{H}$ mutant was prepared and showed the same binding capacity for two divalent metal 
ions, $\mathrm{Zn}(\mathrm{II})$ or $\mathrm{Cd}(\mathrm{II})$, as the wild-type. Determination of the apparent $\mathrm{p} K_{\mathrm{a}}$ values in presence of metal ions revealed that the $\mathrm{pH}$-dependent binding affinity in the site containing the His residue is reduced, and the effect is more pronounced for $\mathrm{Cd}(\mathrm{II})$ than for $\mathrm{Zn}(\mathrm{II})\left(\Delta \mathrm{p} K_{\mathrm{a}} 0.76(1)\right.$ versus

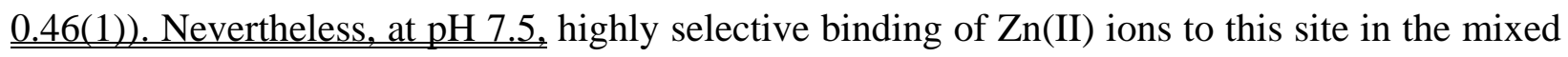
ZnCd species was observed with UV and NMR spectroscopy. In addition, MS spectrometry, supported by results from UV spectroscopy, revealed a difference of the ratio between the $\mathrm{Zn}_{2^{-}}$, $\mathrm{ZnCd}$-, $\mathrm{Cd}_{2}$-species formed after addition of one equiv. of $\mathrm{Cd}(\mathrm{II})$ to the pure $\mathrm{Zn}_{2}$-form. The wildtype domain shows a ratio of roughly $0.25: 0.50: 0.25$, which equals the statistical species distribution in absence of any stabilization effects favouring a certain structure. In contrast, investigation of the $\mathrm{C} 20 \mathrm{H}$ mutant indicates a higher percentage of the mixed $\mathrm{ZnCd}$ species. Most importantly, the introduced Cys-to-His mutation has no major influence of the protein fold as revealed by a number of 2D NMR experiments.

His residues can increase the selectivity of a metal ion binding site for $\mathrm{Zn}$ (II) compared to $\mathrm{Cd}(\mathrm{II})$ as shown previously for a Zn-finger peptide and as observed in the bacterial SmtA MT.[17,28] This preference was now also shown for the smallest possible cluster containing divalent metal ions. The present investigation has fundamental importance and might aid, for example, the analysis and interpretation of spectrophotometric features observed during metalcluster formation of His containing MT sequences. In addition, the further study of such systems might help to understand metal ion specificity and accumulation in vivo.

\section{Abbreviations}

2-PDS 2,2'-dithiodipyridine

Cys cysteine

$\mathrm{E}_{\mathrm{c}} \quad$ early cysteine-labeled

F-AAS flame atomic absorption spectroscopy

GST glutathione S-transferase

His histidine

HSQC heteronuclear single quantum correlation

LMCT ligand-to-metal charge transfer

MS mass spectrometry

MT metallothionein 
PCR polymerase chain reaction

SEC size exclusion chromatography

TOCSY total correlation spectroscopy

TOF time-of-flight

Tris tris(hydroxymethyl)-aminomethan

\section{Appendix A. Supplementary data}

Supplementary data associated with this article can be found in the online version, at http://dx.doi.org/xxx/j.jinorgbio.2015.xxx. These data include: Details of the preparation of the mutants including plasmid sequences, of the calculation of the $\mathrm{Zn}_{2}: \mathrm{ZnCd}: \mathrm{Cd}_{2}$ species ratios, and of the Asp spin system, as well as mass spectra of apo- and $\mathrm{Zn}_{2} \mathrm{C} 20 \mathrm{H}-\gamma-\mathrm{E}_{\mathrm{c}}-1$ and a table with the fitting parameters for the determination of the $\mathrm{p} K_{\mathrm{a}}$ values in Fig. 2.

\section{Acknowledgements}

The authors gratefully acknowledge Dr. Jens Loebus for providing the NMR spectra of wildtype $\gamma-E_{c}-1$ for comparisons and Dr. Serge Chesnov for MS measurements. Financial support comes from the University of Zurich (Forschungskredit to KT), the Swiss National Science Foundation (EF), the Faculty of Natural Sciences, as well as the Department of Chemistry, University of Zurich.

\section{References}

[1] B.L. Vallee, K.H. Falchuk, Physiol. Rev. 73 (1993) 79-118.

[2] L. Tang, R.L. Qiu, Y.T. Tang, S.Z. Wang, Metallomics 6 (2014) 1313-1323.

[3] T.W. Lane, M.A. Saito, G.N. George, I.J. Pickering, R.C. Prince, F.M.M. Morel, Nature 435 (2005) 42-42.

[4] I.F. Rivai, H. Koyama, S. Suzuki, B. Environ. Contam. Tox. 44 (1990) 910-916.

[5] W. Maret, Y. Li, Chem. Rev. 109 (2009) 4682-4707. 
[6] E. Freisinger, Chimia 64 (2010) 217-224.

[7] M. Margoshes, B.L. Vallee, J. Am. Chem. Soc. 79 (1957) 4813-4814.

[8] C.A. Blindauer, J. Inorg. Biochem. 102 (2008) 507-521.

[9] C.A. Blindauer, M.D. Harrison, J.A. Parkinson, A.K. Robinson, J.S. Cavet, N.J. Robinson, P.J. Sadler, Proc. Natl. Acad. Sci. USA 98 (2001) 9593-9598.

[10] M.J. Daniels, J.S. Turner-Cavet, R. Selkirk, H.Z. Sun, J.A. Parkinson, P.J. Sadler, N.J.

Robinson, J. Biol. Chem. 273 (1998) 22957-22961.

[11] O.I. Leszczyszyn, R. Schmid, C.A. Blindauer, Proteins Struct. Funct. Bioinform. 68 (2007) 922-935.

[12] E.A. Peroza, R. Schmucki, P. Güntert, E. Freisinger, O. Zerbe, J. Mol. Biol. 387 (2009) 207218.

[13] C.A. Blindauer, M.T. Razi, D.J. Campopiano, P.J. Sadler, J. Biol. Inorg. Chem. 12 (2007) 393-405.

[14] N. Romero-Isart, N. Cols, M.K. Termansen, J.L. Gelpi, P. Gonzalez-Duarte, S. Atrian, M. Capdevila, P. Gonzalez-Duarte, Eur. J. Biochem. 259 (1999) 519-527.

[15] T.L. Reynolds, R.L. Crawford, Plant Mol. Biol. 32 (1996) 823-829.

[16] O.I. Leszczyszyn, C.R.J. White, C.A. Blindauer, Mol. Biosyst. 6 (2010) 1592-1603.

[17] B.A. Krizek, D.L. Merkle, J.M. Berg, Inorg. Chem. 32 (1993) 937-940.

[18] R.G. Pearson, J. Am. Chem. Soc. 85 (1963) 3533-3539.

[19] J. Loebus, E.A. Peroza, N. Blüthgen, T. Fox, W. Meyer-Klaucke, O. Zerbe, E. Freisinger, J. Biol. Inorg. Chem. 16 (2011) 683-694.

[20] E.A. Peroza, A. Al Kaabi, W. Meyer-Klaucke, G. Wellenreuther, E. Freisinger, J. Inorg. Biochem. 103 (2009) 342-353. 
[21] F. Li, J.I. Mullins, Methods Mol. Biol. 182 (2002) 19-27.

[22] A.O. Pedersen, J. Jacobsen, Eur. J. Biochem. 106 (1980) 291-295.

[23] E. Freisinger, Inorg. Chim. Acta 360 (2007) 369-380.

[24] J. Loebus, PhD Thesis, University of Zurich, 2012.

[25] A.H. Robbins, D.E. McRee, M. Williamson, S.A. Collett, N.H. Xuong, W.F. Furey, B.C.

Wang, C.D. Stout, J. Mol. Biol. 221 (1991) 1269-1293.

[26] J. Cavanagh, W.J. Fairbrother, A.G. Palmer, M. Rance, N.J. Skelton, Journal (2006).

[27] I.M. Armitage, T. Drakenberg, B. Reilly, Met. Ions Life Sci. 11 (2013) 117-144.

[28] C.A. Blindauer, N.C. Polfer, S.E. Keiper, M.D. Harrison, N.J. Robinson, P.R.R. LangridgeSmith, P.J. Sadler, J. Am. Chem. Soc. 125 (2003) 3226-3227. 